\title{
Studies on Preparation and Packaging of Guava Cheese
}

\author{
Rashmi Shukla ${ }^{1 *}$, Y.K. Shukla ${ }^{1}$ and Smita Pathak ${ }^{2}$ \\ ${ }^{1}$ Krishi Vigyan Kendra, B.M. College of Agriculture, Khandwa (M.P.), India \\ ${ }^{2}$ Govt. Home Science College, Jabalpur (M.P.), India \\ *Corresponding author
}

\section{A B S T R A C T}

\begin{tabular}{|l|}
\hline Ke y w o r d s \\
Packaging, \\
$\begin{array}{l}\text { Microbial counts, } \\
\text { Reducing and non- } \\
\text { reducing sugar }\end{array}$ \\
\hline Article Info \\
\hline $\begin{array}{l}\text { Accepted: } \\
\text { 10 January 2018 } \\
\text { Available Online: } \\
\text { 10 February } 2018\end{array}$ \\
\hline
\end{tabular}

\section{Keywords}

Packaging,

Microbial counts,

Reducing and non-

g suga

\section{Introduction}

Guava (Psidium guajava L.). is considered as one of the exquisite, nutritionally valuable and high remunerative crop. It is an important component of human dietary system. The guava fruit is an excellent source of ascorbic acid $(260 \mathrm{mg} / 100 \mathrm{~g})$, pectin (0.52 to $2.0 \%)$, phosphorus (23-27 mg/100 g) and calcium $(14-30 \mathrm{mg} / 100 \mathrm{~g})$. The fresh fruit of guava also provides vitamins like niacin, pantothenic acid, thiamin, riboflavin and vitamin A (Bose et al., 1999). Immature fruits of guava are used in treatment of gastroenteritis, diarrhea, dysentery, blood pressure and cardiovascular diseases (Hisn- Chun Chen, 2007).
Guava is the fourth most widely grown fruit crop in India under the cultivation area of about 0.20 million ha producing $2.50 \mathrm{MT}$ in 2010-2011 (Bijay, 2011). The well-known Indian varieties of guava are Allahbad Safeda, Lucknow-49, Nagpur seedless and Apple guava etc. India ranks second in production of fruits and vegetables, but suffers from postharvest losses due to improper packaging and processing. The avoidance of significant cumulative post-harvest losses i.e., 5-18 \% for fruits and vegetables is a challenging task.

According to CIPHET (2010) the post-harvest loss at national level was of Rs 44,143 crore per annum. 
The physiological and biochemical changes persistently occur after harvest till fruit become unfit for consumption with short shelf life. Now days, different packaging material of processed fruits have gained widespread interest to extend their shelf life. Proper packing with suitable packaging materials improved physio-chemical characteristics of the product i.e., appearance, weight loss, total soluble solids, titrable acidity, ascorbic acid content and total sugars by retarding losses. Cling film also extended the shelf life of Mung bean sprouts up to 5 days (Goyal and Siddiqui, 2012).

Keeping in view the significant effect of different packing materials on shelf life of processed product, the characteristics and the techniques of packaging and the storage temperatures exercise their influence on outcome of wrapping, the present $t$ work was planned to assess the effect of different packaging material of guava cheese on its shelf life.

\section{Materials and Methods}

Fresh and ripened fruits of guava cultivars viz., Lucknow-49, Allahabad safeda, and Apple guava were collected from the guava orchards of Fruit Research Farm, Imalia, J.N. Krishi Vishwa Vidyalaya, and Jabalpur (M.P.) for preparation of the cheese under present investigation. The cheese was prepared from the fruits of each variety under both with and without use of milk powder. Similarly the prepared cheeses were packaged with 4 kinds of packaging materials viz., plastic container, glass container, aluminum foil bag and polythene bag. These treatments were replicated five times in order to minimize the error. Data with respects to characteristics of cheese by using different packaging materials were analyzed (varieties $\mathrm{x}$ formulations $\mathrm{x}$ packaging materials) as per factorial randomized block design

\section{Treatments}

24 (3 varieties $\mathrm{x} 2$ formulation of cheese $\mathrm{x} 4$ packaging materials)

\section{Guava varieties}

Lucknow-49 - $\mathrm{V}_{1}$

Allahabad Safeda $-\mathrm{V}_{2}$

Apple guava $-\mathrm{V}_{3}$

\section{Formulation of cheese}

Without milk powder - $\mathrm{W}_{0}$

With milk powder - $\mathrm{W}_{1}$

\section{Packaging materials}

Plastic container - $\mathrm{P}_{1}$

Glass container - $\mathrm{P}_{2}$

Aluminum foil bag - $\mathrm{P}_{3}$

Polythene bag - $\mathrm{P}_{4}$

Replications - Five

Guava cheese was prepared form the fruit of each variety under both with and without use of milk powder. Storage stability studies of guava cheese was conducted for a period of 150 days at ambient temperature $\left(30^{\circ} \mathrm{c}+2\right.$, 90\% RH). 200g of each Product formulation were cut in to Small pieces and wrapped with butter paper packed in different packaging material viz., plastic container, glass Container, aluminum foil bag and polyether bag, At 30 day intervals, sample were take in triplicate and analyzed for $\mathrm{PH}$, acidity, ascorbic acid, reducing Sugar, non-reducing sugar, total sugar, total microbial as per standard procedures (Sharf 1966). The data were statistically analyzed by the method given by Panse and sukhatme (1963).

\section{Results and Discussion}

The self-life study of guava cheese conducted up to 150 days at ambient condition for 
development of fungal colony and biochemical quality attributes at the interval of 30 days Table 1 . In general, the fungal colonies count was increased with the increasing the duration of storage up to 150 days. As regards for varieties, initially more number of fungal colonies $\left(1.75 \times 10^{6} \mathrm{cfu}\right)$ was noted in the cheese prepared with the use of variety Lucknow-49. The increases in trend of counts of colonies were noted in each interval and maximum counts $\left(11.25 \times 10^{6} \mathrm{cfu}\right)$ were recorded at 150 days of total storage. However, the least counts $1.50 \times 10^{6}, 2.38$ $\times 10^{6}, 3.25 \times 10^{6}, 4.63 \times 10^{6}$ and $10.25 \times 10^{6} \mathrm{cfu}$ were noted at 30,60, 90, 120 and 150 days after storage with Apple guava cheese (Table 1). Similarly no colony forming units were observed by Bramwell and Badrie (2002) in banana cheese. Rai et al., (2005) reported comparatively higher microbial counts in papaya cheese packed in polythene pouches.

The addition of milk powder for the preparation of guava cheese showed significant various among the treatments. Cheese prepared without use of milk powder did not contain any fungal colonies up to 90 days of storage, however after that the growth of fungus noted $\left(1.80 \times 10^{6} \mathrm{cfu}\right)$ and it further increased and become more than double in the next stage i.e. 150 days of storage. The increase in fungal infection in the milk powder added cheese after 90 days might be due to presence of lactic acid bacteria. These finding are in accordance with the findings of Mijacevic et al., (2008).

Whereas the milk powder added cheese get infected just initial stage and noted the fungal counts of $2.83 \times 10^{6}, 4.92 \times 10^{6}, 7.08 \times 10^{6}$, $10.33 \times 10^{6}$ and $17.00 \times 10^{6} \mathrm{cfu}$ at $30,60,90$, 120 and 150 days after storage, respectively.

Amongst the packing materials glass jar proved better over, plastic jar, aluminum foil bags and polythene bags. The cheeses get less infected with fungal mycelia over other packing material of all the intervals of packaging duration. The maximum counts $\left(11.50 \times 10^{6} \mathrm{cfu}\right)$ were noted in polythene bags. Similar finding were also reported by the Kaneker et al., (1992) in mango jam.

Effect of milk powder and packaging on reducing sugar (\%) of guava cheese during storage

The results presented in Table 2 and depicted through Plate 1 showed that there was a periodical increase in reducing sugar content due to influence of varieties, additives and packaging materials up to end of the storage period.

The guava cheese of different varieties showed significant increase in reducing sugar content under different period and increased up to the 150 days. During storage, higher content as well as maximum retention of the same was noted in cheese of Apple guava with the increased value of $32.22,34.82,36.26$, $39.86,41.28$ and 43.96 percent with increasing period of storage table 2 . The increase in reducing sugar was probably due to acid hydrolysis of sucrose and other polysaccharides for their subsequent inversion to reducing sugar (Wills et al., 1980). Similar increase in reducing sugar was recorded in guava papaya and apple cheese Rai et al., (2005).

A significant increase in reducing sugar content of guava cheese was also found due to both the formulation towards the increased storage period. Cheese prepared without milk powder noted 34.26, 35.28, 36.88, 38.98, 39.76 and 40.28 percent reducing sugar at 0 , $30,60,90,120$ and 150 days after storage and exhibited more stability in respect of reducing sugar content during storage as compared to cheese prepared with milk powder. Packaging also significantly influenced the reducing 
sugar content of guava cheese at different storage period.

\section{Change in non-reducing sugar $(\%)$ of guava cheese during storage}

The non-reducing sugar content of guava cheese was determined at 0, 30, 60, 90, 120 and 150 days after storage. A progressive increase in non-reducing sugar content of guava cheese was noticed due to effect of varieties, formulations and packaging materials with increased period of storage.

It is apparent from the data that varieties showed significant increase in non-reducing sugar content up to end of the storage period. The retention of non-reducing sugar content during storage was found maximum in Apple guava $\left(\mathrm{V}_{3}\right)$ and minimum in Lucknow-49 $\left(\mathrm{V}_{1}\right)$ with the value of $28.09,30.56,32.84,34.68$, 36.48 and 38.98 percent and $31.17,32.94$, $34.38,36.42,38.46$ and 40.28 percent at 0,30 , 60, 90, 120 and 150 days after storage table 3 .

\section{Change in total sugar (\%) of guava cheese during storage}

Progressive increase in total sugar content of guava cheese due to the effect of varieties, formulations and packaging materials as the storage period increased up to 150 days.

The maximum total sugar content was recorded in Allahabad safeda which also exhibited less changes of the same during storage in comparison to Lucknow-49 and Apple guava at 0, 30, 60, 90, 120 and 150 days after storage.

Maximum total sugar content was noted in case of cheese of milk powder treatment but more stability regarding the total sugar during storage was recorded in treatment without milk powder with the value of $70.59,73.08$, $75.52,78.92,82.36$ and $85.60 \%$ and 64.12 ,
$67.00,69.04,72.66,75.58$ and $78.46 \%$ at 0 , $30,60,90,120$ and 150 days after storage table 4.

The total sugar content under polythene bag packing recorded 67.96, 71.90, 74.38, 76.94, 79.62 and $82.92 \%$ followed by aluminum foil bag with $67.96,72.34,75.14,76.84,79.57$ and $82.32 \%$ at $0,30,60,90,120$ and 150 days after storage, respectively and exhibited higher content as well as less variation regarding the total sugar content during storage as compared to other packaging materials.

Reducing sugar content increased with subsequent increase in storage period. This phenomenon might be due to hydrolysis of polysaccharides and inversion of non-reducing sugar in to reducing sugar.

A remarkable increase in reducing and nonreducing sugar in stored guava pulp has been reported by Nagtode (2007).

\section{Change in total titrable acidity (\%) of guava cheese during storage}

In all three varieties had significant effect on the total titrable acidity of guava cheese up to 150 days of storage. It was found that variety Lucknow-49 had higher total titrable acidity followed by Allahabad safeda whereas, Apple guava exhibited less fluctuation with respect to titrable values up to 150 days of storage.

Addition of milk powder during preparation of cheese caused significant reduction in titrable acidity of cheese recorded at 0, 30, 60, 90, 120 and 150 days. Treatment without milk powder had higher total titrable acidity $(0.32,0.28$, $0.24,0.21,0.81$ and $0.15 \%$ at $0,30,60,90$, 120 and 150 days after storage, respectively, as well as it expressed more stability of the same as compared to treatment with milk powder at $0,30,60,90,120$ and 150 days after storage table 5 . 
Table.1 Fungal colony counts (cfu) of guava cheese stored under various treatments (in days)

\begin{tabular}{|l|l|l|l|l|l|}
\multicolumn{1}{|c|}{ Treatment } & \multicolumn{1}{|c|}{$\mathbf{3 0}$ days } & \multicolumn{1}{|c|}{$\mathbf{6 0}$ days } & \multicolumn{1}{c|}{$\mathbf{9 0}$ days } & \multicolumn{1}{c|}{ days } & \multicolumn{1}{c|}{$\mathbf{1 5 0}$ days } \\
\hline Variety & & & & & \\
\hline Lucknow-49 & $1.75 \times 10^{6}$ & $2.63 \times 10^{6}$ & $4.13 \times 10^{6}$ & $6.25 \times 10^{6}$ & $11.25 \times 10^{6}$ \\
\hline Allahabad safeda & $1.50 \times 10^{6}$ & $2.38 \times 10^{6}$ & $3.25 \times 10^{6}$ & $4.63 \times 10^{6}$ & $10.38 \times 10^{6}$ \\
\hline Apple guava & $1.50 \times 10^{6}$ & $2.38 \times 10^{6}$ & $3.5 \times 10^{6}$ & $4.63 \times 10^{6}$ & $10.25 \times 10^{6}$ \\
\hline Formulation & & & & & \\
\hline Without milk powder & $0.00 \times 10^{6}$ & $0.00 \times 10^{6}$ & $0.00 \times 10^{6}$ & $1.80 \times 10^{6}$ & $3.58 \times 10^{6}$ \\
\hline With milk powder & $2.83 \times 10^{6}$ & $4.92 \times 10^{6}$ & $7.08 \times 10^{6}$ & $10.33 \times 10^{6}$ & $17.00 \times 10^{6}$ \\
\hline Packaging & $1.60 \times 10^{6}$ & $2.60 \times 10^{6}$ & $3.60 \times 10^{6}$ & $5.00 \times 10^{6}$ & $10.80 \times 10^{6}$ \\
\hline Plastic jar & $1.00 \times 10^{6}$ & $1.67 \times 10^{6}$ & $2.83 \times 10^{6}$ & $4.50 \times 10^{6}$ & $9.83 \times 10^{6}$ \\
\hline Glass jar & $1.83 \times 10^{6}$ & $3.00 \times 10^{6}$ & $4.17 \times 10^{6}$ & $6.00 \times 10^{6}$ & $10.67 \times 10^{6}$ \\
\hline Aluminium Foil bag & $1.50 \times 10^{6}$ & $3.00 \times 10^{6}$ & $4.17 \times 10^{6}$ & $6.00 \times 10^{6}$ & $11.50 \times 10^{6}$ \\
\hline Polythene bag & & & & & \\
\hline
\end{tabular}

Table.2 Change in reducing sugar $(\%)$ of guava cheese during storage as influenced by different treatment (in days)

\begin{tabular}{|c|c|c|c|c|c|c|}
\hline Treatments & 0 & 30 & 60 & 90 & 120 & 150 \\
\hline \multicolumn{7}{|l|}{ Variety } \\
\hline Lucknow-49 & 36.48 & 38.42 & 40.62 & 42.28 & 44.30 & 46.16 \\
\hline Allahabad safeda & 34.10 & 36.28 & 38.92 & 40.68 & 42.16 & 44.76 \\
\hline Apple guava & 32.22 & 34.82 & 36.26 & 39.86 & 41.28 & 43.96 \\
\hline SEm \pm & 1.14 & 1.23 & 1.24 & 0.85 & 0.95 & 0.99 \\
\hline CD $(5 \%)$ & 3.42 & 3.68 & 3.72 & 2.56 & 2.86 & 2.98 \\
\hline \multicolumn{7}{|l|}{ Formulation } \\
\hline Without milk powder & 34.26 & 35.28 & 36.88 & 38.98 & 39.76 & 40.28 \\
\hline With milk powder & 38.12 & 39.32 & 40.26 & 41.28 & 42.68 & 43.38 \\
\hline SEm \pm & 1.06 & 1.21 & 1.25 & 0.73 & 0.87 & 0.95 \\
\hline CD $(5 \%)$ & 3.18 & 3.62 & 3.76 & 2.18 & 2.62 & 2.84 \\
\hline \multicolumn{7}{|l|}{ Packaging } \\
\hline Plastic jar & 35.70 & 36.72 & 38.62 & 39.28 & 40.32 & 41.68 \\
\hline Glass jar & 35.70 & 36.68 & 38.52 & 39.10 & 40.08 & 41.28 \\
\hline Aluminum Foil bag & 35.70 & 37.88 & 39.86 & 40.98 & 41.92 & 42.86 \\
\hline Polythene bag & 35.70 & 37.16 & 39.16 & 40.82 & 41.80 & 42.66 \\
\hline SEm \pm & 0.19 & 0.56 & 0.57 & 0.62 & 0.63 & 0.66 \\
\hline CD $(5 \%)$ & 0.57 & 1.67 & 1.72 & 1.86 & 1.90 & 1.98 \\
\hline
\end{tabular}


Table.3 Change in non-reducing sugar (\%) of guava cheese during storage as influenced by different treatment (in days)

\begin{tabular}{|c|c|c|c|c|c|c|}
\hline Treatments & 0 & 30 & 60 & 90 & 120 & 150 \\
\hline \multicolumn{7}{|l|}{ Variety } \\
\hline Lucknow-49 & 31.17 & 32.94 & 34.38 & 36.42 & 38.46 & 40.28 \\
\hline Allahabad safeda & 30.28 & 32.52 & 33.96 & 35.44 & 37.46 & 38.26 \\
\hline Apple guava & 28.09 & 30.56 & 32.84 & 34.68 & 36.48 & 37.98 \\
\hline SEm \pm & 0.73 & 0.77 & 0.88 & 0.91 & 0.93 & 0.99 \\
\hline CD $(5 \%)$ & 2.18 & 2.32 & 2.65 & 2.72 & 2.80 & 2.96 \\
\hline \multicolumn{7}{|l|}{ Formulation } \\
\hline Without milk powder & 29.86 & 31.72 & 32.16 & 33.68 & 35.82 & 38.18 \\
\hline With milk powder & 32.47 & 33.76 & 35.26 & 37.64 & 39.76 & 42.22 \\
\hline SEm \pm & 0.72 & 0.76 & 0.89 & 1.16 & 1.22 & 1.25 \\
\hline CD (5\%) & 2.15 & 2.28 & 2.68 & 3.48 & 3.66 & 3.76 \\
\hline \multicolumn{7}{|l|}{ Packaging } \\
\hline Plastic jar & 32.26 & 33.14 & 35.68 & 37.92 & 39.86 & 41.78 \\
\hline Glass jar & 32.26 & 33.60 & 35.54 & 37.65 & 39.46 & 41.28 \\
\hline Aluminium Foil bag & 32.26 & 34.46 & 35.28 & 35.86 & 37.65 & 39.46 \\
\hline Polythene bag & 32.26 & 34.74 & 35.22 & 36.12 & 37.82 & 39.26 \\
\hline SEm \pm & 0.14 & 0.23 & 0.32 & 0.73 & 0.78 & 0.83 \\
\hline CD $(5 \%)$ & NS & 0.68 & 0.96 & 2.19 & 2.34 & 2.48 \\
\hline
\end{tabular}

Table.4 Change in total sugar (\%) of guava cheese during storage as influenced by different treatments (in days)

\begin{tabular}{|c|c|c|c|c|c|c|}
\hline Treatments & 0 & 30 & 60 & 90 & 120 & 150 \\
\hline \multicolumn{7}{|l|}{ Variety } \\
\hline Lucknow-49 & 67.65 & 71.36 & 75.00 & 78.70 & 82.76 & 86.44 \\
\hline Allahabad safeda & 64.38 & 68.80 & 72.88 & 76.12 & 79.62 & 83.02 \\
\hline Apple guava & 60.31 & 65.38 & 69.10 & 74.54 & 77.76 & 82.94 \\
\hline SEm \pm & 2.15 & 1.76 & 1.88 & 1.16 & 1.25 & 1.24 \\
\hline CD (5\%) & 6.46 & 5.28 & 5.64 & 3.48 & 4.56 & 3.72 \\
\hline \multicolumn{7}{|l|}{ Formulation } \\
\hline Without milk powder & 64.12 & 67.00 & 69.04 & 72.66 & 75.58 & 78.46 \\
\hline With milk powder & 70.59 & 73.08 & 75.52 & 78.92 & 82.36 & 85.60 \\
\hline SEm \pm & 1.79 & 1.23 & 1.89 & 1.94 & 2.16 & 2.23 \\
\hline CD (5\%) & 5.36 & 3.68 & 5.68 & 5.82 & 6.47 & 6.68 \\
\hline \multicolumn{7}{|l|}{ Packaging } \\
\hline Plastic jar & 67.96 & 69.86 & 74.30 & 77.20 & 80.18 & 83.46 \\
\hline Glass jar & 67.96 & 70.28 & 74.06 & 76.75 & 79.54 & 82.56 \\
\hline Aluminium Foil bag & 67.96 & 72.34 & 75.14 & 76.84 & 79.57 & 82.32 \\
\hline Polythene bag & 67.96 & 71.90 & 74.38 & 76.94 & 79.62 & 82.92 \\
\hline SEm \pm & 0.10 & 0.74 & 0.11 & 0.14 & 0.19 & 0.24 \\
\hline CD 5\% & 0.30 & 2.34 & 0.32 & 0.43 & 0.58 & 0.72 \\
\hline
\end{tabular}


Table.5 Change in total titrable acidity (\%) of guava cheese during storage as influenced by different treatments (in days)

\begin{tabular}{|l|c|c|c|c|c|c|}
\hline Treatments & $\mathbf{0}$ & $\mathbf{3 0}$ & $\mathbf{6 0}$ & $\mathbf{9 0}$ & $\mathbf{1 2 0}$ & $\mathbf{1 5 0}$ \\
\hline Variety & 0.34 & 0.30 & 0.26 & 0.22 & 0.19 & 0.16 \\
\hline Lucknow-49 & 0.30 & 0.27 & 0.24 & 0.21 & 0.17 & 0.14 \\
\hline Allahabad safeda & 0.26 & 0.23 & 0.19 & 0.17 & 0.14 & 0.10 \\
\hline Apple guava & $\mathbf{0 . 0 0 8}$ & $\mathbf{0 . 0 0 9}$ & $\mathbf{0 . 0 0 7}$ & $\mathbf{0 . 0 0 3}$ & $\mathbf{0 . 0 0 2}$ & $\mathbf{0 . 0 0 2}$ \\
\hline SEm \pm & $\mathbf{0 . 0 2 5}$ & $\mathbf{0 . 0 2 7}$ & $\mathbf{0 . 0 2 1}$ & $\mathbf{0 . 0 0 9}$ & $\mathbf{0 . 0 0 7}$ & $\mathbf{0 . 0 0 6}$ \\
\hline CD (5\%) & & & & & & \\
\hline Formulation & 0.32 & 0.28 & 0.24 & 0.21 & 0.18 & 0.15 \\
\hline Without milk powder & 0.28 & 0.25 & 0.21 & 0.18 & 0.15 & 0.12 \\
\hline With millk powder & $\mathbf{0 . 0 0 8}$ & $\mathbf{0 . 0 0 9}$ & $\mathbf{0 . 0 0 7}$ & $\mathbf{0 . 0 0 6}$ & $\mathbf{0 . 0 0 5}$ & $\mathbf{0 . 0 0 5}$ \\
\hline SEm & $\mathbf{0 . 0 2 4}$ & $\mathbf{0 . 0 2 7}$ & $\mathbf{0 . 0 2 1}$ & $\mathbf{0 . 0 1 8}$ & $\mathbf{0 . 0 1 5}$ & $\mathbf{0 . 0 1 6}$ \\
\hline CD (5\%) & & & & & & \\
\hline Packaging & 0.30 & 0.27 & 0.24 & 0.21 & 0.18 & 0.16 \\
\hline Plastic jar & 0.30 & 0.28 & 0.26 & 0.24 & 0.21 & $\mathbf{0 . 1 9}$ \\
\hline Glass jar & 0.30 & 0.25 & 0.21 & 0.17 & 0.15 & $\mathbf{0 . 1 0}$ \\
\hline Aluminium Foil bag & 0.30 & 0.26 & 0.21 & 0.18 & 0.12 & $\mathbf{0 . 0 9}$ \\
\hline Polythene bag & $\mathbf{0 . 0 2}$ & $\mathbf{0 . 0 0 6}$ & $\mathbf{0 . 0 9}$ & $\mathbf{0 . 0 0 4}$ & $\mathbf{0 . 0 0 3}$ & $\mathbf{0 . 0 0 8}$ \\
\hline SEm \pm & NS & NS & NS & NS & NS & NS \\
\hline CD 5\% & & & &
\end{tabular}

Table.6 Change in ascorbic acid $(\mathrm{mg} / 100 \mathrm{~g})$ of guava cheese prepared under different treatments and subsequent storage for different periods (in days)

\begin{tabular}{|c|c|c|c|c|c|c|}
\hline Treatments & 0 & 30 & 60 & 90 & 120 & 150 \\
\hline \multicolumn{7}{|l|}{ Variety } \\
\hline Lucknow-49 & 37.52 & 33.66 & 30.63 & 28.06 & 24.76 & 20.92 \\
\hline Allahabad safeda & 32.36 & 30.26 & 27.05 & 24.16 & 21.86 & 19.20 \\
\hline Apple guava & 30.96 & 28.55 & 25.05 & 22.95 & 21.20 & 18.07 \\
\hline SEm \pm & 1.76 & 1.43 & 1.56 & 1.77 & 0.87 & 0.62 \\
\hline CD $(5 \%)$ & 5.26 & 4.35 & 4.70 & 5.39 & 2.60 & 1.85 \\
\hline \multicolumn{7}{|l|}{ Formulation } \\
\hline Without milk powder & 35.29 & 32.55 & 29.67 & 26.32 & 23.85 & 20.00 \\
\hline With milk powder & 31.93 & 29.10 & 25.62 & 23.79 & 21.38 & 18.80 \\
\hline SEm \pm & 1.32 & 0.95 & 1.17 & 0.86 & 0.49 & 0.59 \\
\hline CD (5\%) & NS & 2.86 & 3.52 & 2.58 & 1.46 & 1.78 \\
\hline \multicolumn{7}{|l|}{ Packaging } \\
\hline Plastic jar & 33.62 & 31.74 & 29.24 & 26.56 & 24.21 & 21.16 \\
\hline Glass jar & 33.62 & 32.01 & 29.90 & 27.94 & 25.64 & 22.38 \\
\hline Aluminium Foil bag & 33.62 & 29.98 & 26.99 & 23.51 & 20.68 & 17.60 \\
\hline Polythene bag & 33.62 & 29.56 & 25.79 & 22.22 & 19.92 & 16.44 \\
\hline SEm \pm & 0.27 & 0.82 & 0.86 & 1.24 & 1.41 & 1.88 \\
\hline CD (5\%) & NS & 2.47 & 2.58 & 3.72 & 4.24 & 5.65 \\
\hline
\end{tabular}




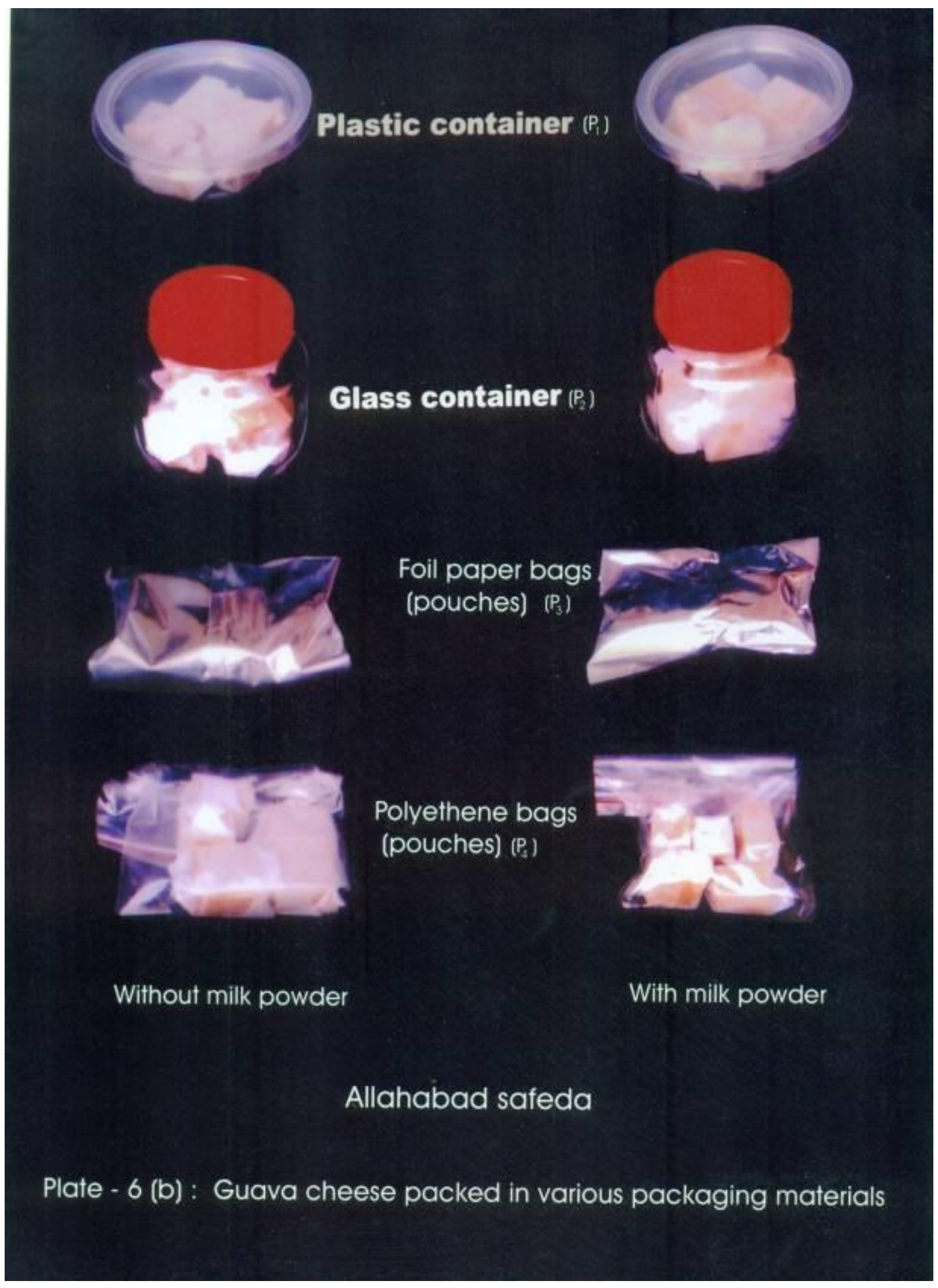




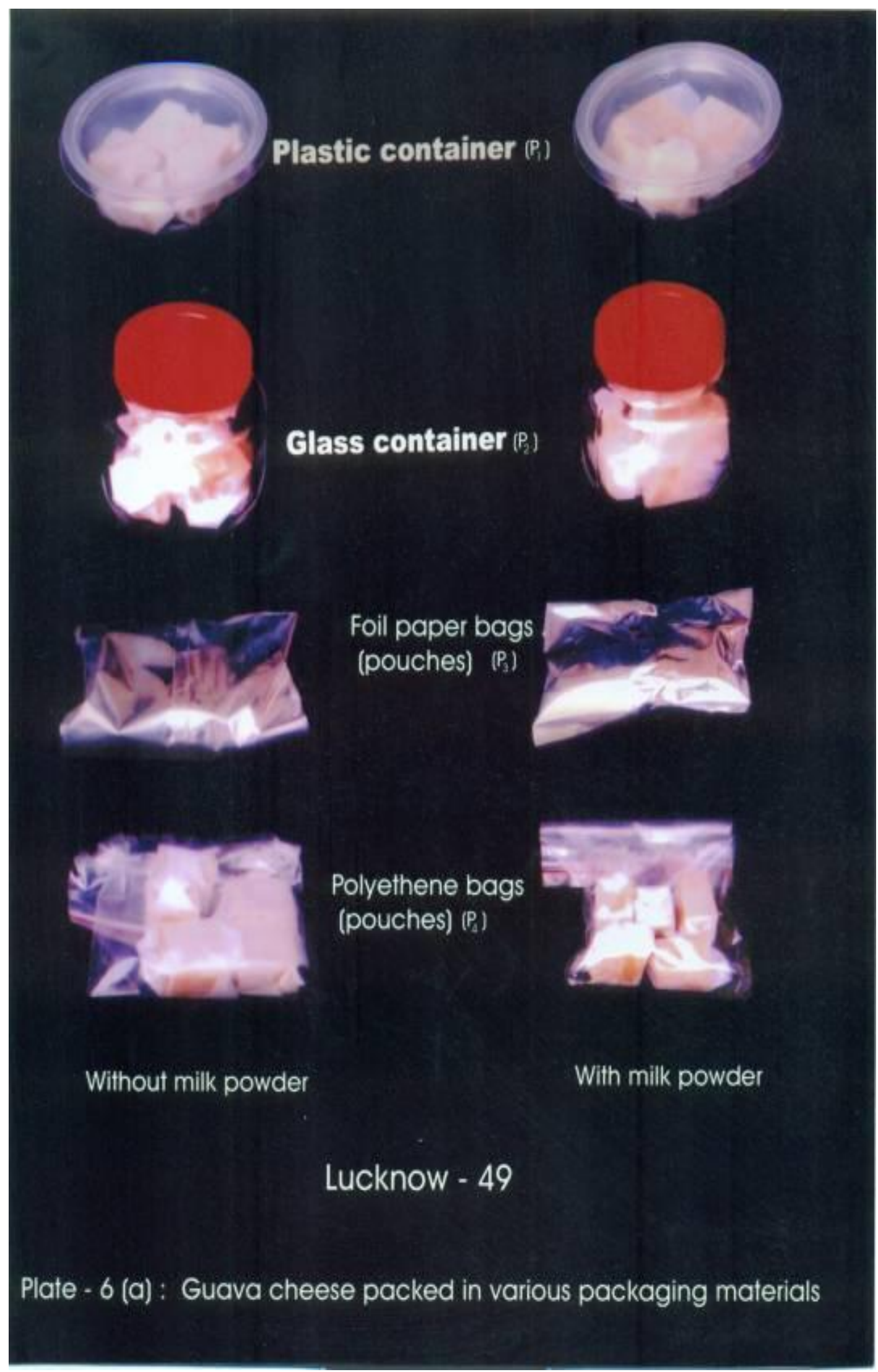




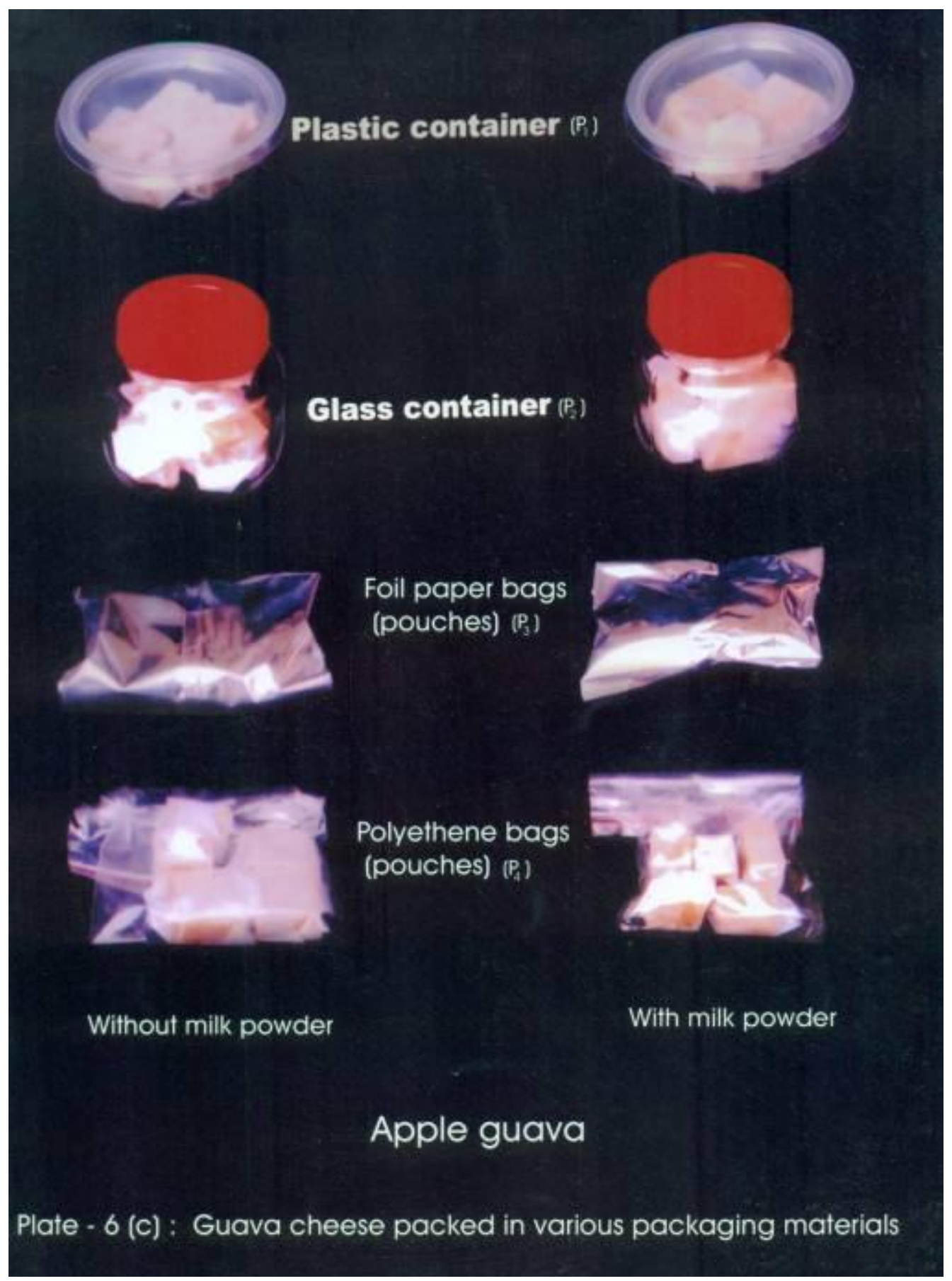

Total titrable acidity of guava cheese was not very much affected by various packaging materials at different storage periods. However, lesser changes in total titrable acidity were noted in treatment plastic container with the value of $0.30,0.27,0.24$, $0.21,0.18$ and $0.16 \%$ which was similar to treatment glass container recorded at 0,30 ,
60, 90, 120 and 150 days after storage, respectively. These results are in consonance with the results of Baramanray et al., (1996) in guava Jelly and Baramanray and Gupta (1994) in guava cheese.

The cheese prepared from Allahabad safeda possessed less acidity as well as less reduction 
of the same with the duration than Lucknow 49. The highest reduction of acidity in guava cheese prepared from Lucknow 49 has also been reported by Nagtode (2007) and reported that the decrease in acidity in guava cheese during storage might be due to utilization of acids for stronger gel formation.

Further it was observed that the total titrable acidity of guava cheese was not very much affected by various packaging materials at different storage periods. However lesser change in total titrable acidity was noted in plastic container which was found quite similar as glass container during 150 days of storage as compared to remaining treatments. The reduction in acidity during storage was also found in other fruit cheese by Singh et $a l$. , (2005) and in guava cheese by Mehato (2006).

\section{Change in ascorbic acid (mg/100 g) of guava cheese during storage}

The ascorbic acid content of stored guava cheese was determined at 30 days intervals from 0 days up to 150 days of storage. The gradual decrease in ascorbic acid content of guava cheese due to effect of varieties additives and packaging materials up to 150 days of storage.

Cheese prepared from pulp of different guava varieties showed significant decline in ascorbic acid content up to 150 days of storage. Treatment Lucknow-49 exhibited higher content $(37.52,33.66,30.63,28.06$, 24.76 and $20.92 \mathrm{mg} / 100 \mathrm{~g}$ ) and showed least looses in ascorbic acid during storage in comparison to Allahabad safeda and Apple guava noted at $0,30,60,90,120$ and 150 days after storage, respectively

Addition of milk powder added cheese increase in duration from 0 to onward it showed a steep decline for the same up to 150 days of storage. Maximum retention of ascorbic acid up to 150 days was recorded in treatment of without milk powder product and was considered to be more stable as compared to treatment with milk powder the value of $35.29,32.55,29.67,26.32,23.85$ and 20.00 $\mathrm{mg} / 100 \mathrm{~g}$ and $321.93,29.10,25.62,23.79$. 21.38 and $18.80 \mathrm{mg} / 100 \mathrm{~g}$ noted at $0,30,60$, 90, 120 and 150 days after storage, respectively.

Moreover, different packaging materials also shown to have significant effect on ascorbic acid content of guava cheese upto 150 days of storage. Although the changes in ascorbic acid content due to various packaging materials were found to be quite similar, but treatment polythene bags was considered to have highest retention of ascorbic acid (33.44, $38.60,40.72$, 48.54, 52.77 and $58.50 \mathrm{mg} / 100 \mathrm{~g}$ ) table 6 as it showed mild fluctuation in the content of ascorbic acid was observed during storage as compared to others.

The highest mean ascorbic acid content was observed in guava cheese prepared form Lucknow 49. The cheese prepared from variety Lucknow 49 had maximum retention of ascorbic acid content during storage. The present findings are in conformity with the results of Baramanray and Gupta (1994).

The ascorbic acid content decreased markedly during storage up to 150 days and the least reduction was observed in cheese prepared by using milk powder. The similar findings have also been reported by Mehato (2006) and Nagtode (2007) in guava cheese.

\section{Acknowledgment}

The authors are grateful to the Department of Food and Nutrition Government M.H. College of Home Science and Science for women, Jabalpur for providing me technical assistance and facilities to execute this study. 


\section{References}

Baramanray, A. and Gupta, O.P. 1994. Evaluation of guava hybrids for making cheese. Haryana J. Hort. Sci., 23(2): 18113.

Baramanray, A., Gupta, O.P. and Dhawan, S.S. 1996. Comparison of guava hybrids with commercial cultivars for making jelly. Haryana J. Hort. Sci., 24(2): 196204.

Bijay K, 2011 Editor. Indian horticulture database. New Delhi: Aristo.

Bose, T.K., Mitra, S.K., Farooqui, A.A. and Sandhu, M.K. 1999. Tropical Horticulture, 1: 297.

Bramwell, M.G. and Badrie, N. 2002. Processing and quality evaluation of banana (Musa acuminate). J. Food. Science \& Tec., 39(5): 537-541.

Goyal A, Siddiqui S. 2012 Effects of ultraviolet irradiation, pulsed electric field, hot water dip and ethanol vapours treatment on keeping and sensory quality of Mung bean (Vigna radiata $\mathrm{L}$. Wilczek) sprouts. J Food Science \& Tech.

Hisn-Chun Chen, Ming Jen Shen, Liyun Lin and Chung May Wu 2007. Nutritional composition and volatile compounds in Guava (Fresh Produce), 1(2): 132-139.

Kaneker. U.J., Joshi, S.V. and Chavan, K.D. 1992. Development and evaluation of Mango Jam. Ind. Fd. Packer, 34(4): 1215.

Mehato, P.K.2006. Identification of suitable varieties of guava for preparation of quality cheese. M.Sc. Thesis JNKVV, Jabalpur (M.P.)

Mijacevic. Z and Bulajic, S 2008. Sensory evaluation and microbiological characterization of cheese. Acta Veterinaria, 58(5/6): 531-541.

Nagtode, Khelendra 2007. Standardization of formulation for the preparation of Guava (Psidium guajava L.) cheese and its storage. M.Sc. Thesis JNKVV, Jabalpur (M.P.).

Panshe, V.G. and Sukhatme, P.V. 1963. Statistical methods for agriculture worker, ICAR publication, New Delhi.

Rai, Surabhi, Sethi Vijay and Jayachandra, K.S. 2005. Storage studies in guava cheese. Annals of Agri-Bio Research, 10(1): 97-100.

Rai, Surabhi, Sethi, V. and Jayachandran, K.S. 2005. Equilibrium relative humidity (ERH) studies of guava cheese. Annals of Agri. Bio-Research, 10(1): 93-95.

Sharf, J.M. 1966. Recommended method for microbial examination of foods. American public Health Association Inc, New York.

Singh, P. Shukla, A., Singh, Ranjana and Singh, A.K. 2005. Utilization of Guava juice by value addition through blended beverages. $1^{\text {st }}$ International Guava Symposium, December, p. 108

Wills, R., Mc-Glosson, B., Graham, D. and Joyee, D. 1980. Post-harvest -An introduction to the physiology handling of fruits, vegetables and ornamentals $4^{\text {th }}$ Edn

\section{How to cite this article:}

Rashmi Shukla, Y.K. Shukla and Smita Pathak. 2018. Studies on Preparation and Packaging of Guava Cheese. Int.J.Curr.Microbiol.App.Sci. 7(02): 1159-1170.

doi: https://doi.org/10.20546/ijcmas.2018.702.143 